\title{
Sprawozdanie
}

\section{Konferencja naukowa nt.: \\ Podejścia badawcze i metodologie w nauce o polityce, \\ Kraków, 16-17 września 2010 r.}

Konferencja naukowa „Podejścia badawcze i metodologie w nauce o polityce” zorganizowana została przez Zakład Teorii Polityki i Państwa Uniwersytetu Jagiellońskiego Instytutu Nauk Politycznych i Stosunków Międzynarodowych UJ, pod patronatem Prorektora do spraw Dydaktyki UJ prof. dr hab. A. Mani, Polskiego Towarzystwa Nauk Politycznych, Komitetu Nauk Politycznych PAN oraz Urzędu Marszałkowskiego Województwa Małopolskiego. Przewodniczącą Komitetu Organizacyjnego Konferencji była Pani Profesor dr hab. B. Krauz-Mozer.

Problematyka konferencji związana $\mathrm{z}$ metodologią nauk o polityce okazała się zagadnieniem aktualnym i budzącym ogromne zainteresowanie, o czym świadczy liczne grono uczestników z niemal wszystkich ośrodków akademickich w kraju. Podczas konferencji wystąpiło niemal czterdziestu prelegentów reprezentujących nauki polityczne, ale także takie kierunki, jak socjologia, historia, ekonomia oraz stosunki międzynarodowe.

O randze konferencji najlepiej świadczy fakt, że jej inauguracji dokonali tak wybitni badacze reprezentujący nauki polityczne, jak: prof. dr hab. B. Krauz-Mozer, Przewodnicząca Komitetu Organizacyjnego i kierownik Zakładu Teorii Polityki i Państwa Instytutu Nauk Politycznych i Stosunków Międzynarodowych, Prorektor Uniwersytetu Jagiellońskiego, kierownik Katedry Historii Dyplomacji i Polityki Międzynarodowej, prof. dr hab. A. Mania, Dziekan Wydziału Studiów Międzynarodowych i Politycznych UJ, prof. dr hab. B. Szlachta, prof. dr hab. W. Bernacki, Dyrektor Instytutu Nauk Politycznych i Stosunków Międzynarodowych, prof. dr hab. T. Sasińska-Klas, Prezes Polskiego Towarzystwa Nauk Politycznych, prof. dr hab. K. Pałecki, Członek Komitetu Wykonawczego Central European Political Science Association. 
Merytoryczna część konferencji rozpoczęła się sesją plenarną „Jak badać to, co polityczne"?, w której zaprezentowane zostały trzy wystąpienia: prof. dr. hab. M. Karwata z Uniwersytetu Warszawskiego pt. Cztery płaszczyzny badania polityki (metawiedzy, esencji, formy, pragmatyki), następnie prof. dr. hab. A. Jabłońskiego z Uniwersytetu Wrocławskiego zatytułowany Podejścia $i$ metodologie $w$ badaniach zmiany systemów politycznych oraz prof. dr. hab. T. Klementewicza z Uniwersytetu Warszawskiego pt. Politolog w labiryncie paradygmatów - pułapki eklektyzmu. Sesja ta w niezwykle interesujący sposób wprowadziła uczestników w świat wątpliwości i kontrowersji towarzyszących współczesnym metodom i podejściom badawczym w naukach o polityce.

Dalsza konferencja podzielona została na sesje panelowe, toczące się równolegle. Nie sposób w sprawozdaniu wymienić wszystkich referentów, zwłaszcza że sprawozdawca nie mógł uczestniczyć ze zrozumiałych względów we wszystkich panelach, jednak z punktu widzenia badania ustrojów i systemów politycznych szczególnie frapujące wydały się sesje poświęcone teorii polityki (Sesja „Wokół teorii polityki”, moderowana przez prof. dr. hab. A. Jabłońskiego) z wystąpieniami prof. dra hab. Z. Bloka z Uniwersytetu im. Adama Mickiewicza Rodzaje teoretycznej wiedzy o polityce a podejścia badawcze, dr. B. Kaczmarka z Uniwersytetu Warszawskiego poświęconym porównaniu metodologii nauk o polityce i nauk o organizacji (Teoria polityki a teoria organizacji. Kilka propozycji) oraz dr. P. Łukomskiego z Uniwersytetu Zielonogórskiego Teoria polityki porządku dyskursu według koncepcji J.G. Gunnella. Sesja ta, łącznie z dyskusją, jaka towarzyszyła wystąpieniom, dała asumpt przekonaniu prelegentów i dyskutantów o silnych związkach nauk o polityce $\mathrm{z}$ naukami socjologicznymi, zarazem prof. K. Pałecki zwrócił uwagę, że w nauce o polityce wyróżnienie ontologiczne nie narzuca metody, to jest wyróżnienia epistemologicznego, natomiast tak w naukach o polityce jak i innych naukach humanistycznych obowiązkiem badacza jest ujawnienie założeń aksjologicznych przyjmowanych badaniach i nauce - brak ujawnienia takich założeń może nie tylko zniekształcić, ale w ogóle wypaczyć odbiór efektów badań i zamierzenia autora.

W równoległej sesji panelowej zatytułowanej „Podejścia i metody w stosunkach międzynarodowych”, moderowanej przez prof. dr. hab. R. Bäckera wygłoszone zostały cztery wystąpienia poświęcone badaniom politycznej przestrzeni międzynarodowej. Były to wystąpienia: prof. dr hab. T. Łoś-No- 
wak O potrzebie rekonstrukcji przestrzeni badawczej w nauce o stosunkach międzynarodowych, prof. dr. hab. G. Lisowskiego Metody głosowania w organizacjach międzynarodowych, dr. T. Klina Konstruktywizm jako podejście w badaniu międzynarodowych stosunków politycznych oraz dr. B. Sajduka Czy $w$ nauce o stosunkach międzynarodowych możliwe jest efektywne prognozowanie?.

W kolejnej sesji panelowej, poświęconej metodologii przedmiotowej nauki o polityce, moderowanej przez prof. dr. hab. T. Klementewicza zaprezentowano trzy wystąpienia przedstawiające trzy koncepcje i metody badawcze: koncepcję metodologii zaczerpniętą z badań historycznych (Aplikacje koncepcji metodologicznych M. Handelsmana w nauce o polityce prof. dr. hab. W. Hadkiewicza i dr. A. Iliów), metodę abdukcji (Metoda abdukcji oraz jej zastosowanie na gruncie nauki o polityce dr. F. Pierzgalskiego oraz analizy systemowej (Systemowa analiza polityki w świetle rekonstrukcji funkcjonalizmu J. C. Alexandra dr. J. Noconia).

Równolegle zaprezentowana została sesja dotycząca wyzwań globalizacyjnych w politologii, podczas której zaprezentowano trzy wystąpienia, prof. dr. hab. R. Bäckera, dr. P. Potockiego oraz mgr M. Kozub poświęcone zagadnieniom globalizacji we współczesnej nauce. W tej sesji szczególnie warto podkreślić niezwykle wartościowy poznawczo głos dr. Potockiego, który przedstawił stan badań politologii amerykańskiej i europejskiej w pierwszej dekadzie XXI wieku na podstawie analizy porównawczej zawartości „American Journal of Political Science” i „British Journal of Political Science”.

W dwóch ostatnich sesjach panelowych pierwszego dnia konferencji przedstawione zostały kolejne zagadnienia badań politologicznych. W pierwszej z nich, zatytułowanej „Dylematy badań politologicznych” i moderowanej przez prof. dr. hab. M. Karwata zaprezentowali swoje wystąpienia prof. dr hab. B. Szklarski, przedstawiając stan badań i metod badawczych przywództwa (Jak badać przywództwo polityczne?), dr Ł. Młyńczyk prezentując wystawienie Czy możliwe jest wykorzystanie paradygmatu koincydencji? oraz mgr A. Gorgosz z ciekawą i obrazową prezentacją scenariuszowej metody prognozowania zjawisk społeczno-politycznych.

Równolegle odbywała się sesja poświęcona problemom badań ilościowych w naukach o polityce, gdzie zaprezentowano cztery wystąpienia dotyczące podejścia ilościowego i uwarunkowań badań pomiarowych, zaprezentowane 
przez dr. Ł. Wordliczka, dr. W. Szewczaka, mgr. R. Marzęckiego oraz mgr I. Reichardt.

Drugi dzień konferencji rozpoczęły sesja panelowa pod frapującym tytułem „Czy wartości mają znaczenie?”, w której zaprezentowały się cztery osoby: dr J. Kołodziej z tekstem poświęconym problemom badawczym aksjologii działań politycznych, dr M. Bachryj-Krzyważnia, przedstawiający psychoanalityczne i hermeneutyczne inspiracje w badaniu i rozumieniu działań aktorów politycznych, dr L. Rubisz ze sceptycznym wystąpieniem o ograniczeniach i możliwościach naukowego poznania rzeczywistości politycznej oraz dr Ł. Dominiak, który przedstawił problem wartościowani w naukach społecznych w kontekście koncepcji J. M. Finnisa. Równolegle odbyła się sesja zatytułowana „Politologia jako nauka społeczna” poświęcona metodom badania zjawisk politycznych zaczerpniętym $\mathrm{z}$ nauk społecznych, to jest teorii gier, a dokładnie gier oceanicznych (z nieokreśloną, wielką ilością uczestników) - z prezentacją dr. M. Jasińskiego Łączenie się i podziat koalicji $w$ świetle teorii gier oceanicznych, metoda indeksowa - wystąpienie dr. B. Michalaka Przydatność metody indeksowej dla analizy relewancji partii politycznych, wystąpieniem dr. J. Harmana Metody podziału wpływów i stanowisk między podmioty polityczne $w$ świetle teorii wyboru społecznego oraz dr M. Kasprowicz o metodach mieszanych i ich zastosowaniu w badaniach partii politycznych. Ta sesja poświęcona została metodom ilościowym, dzięki którym badanie partii politycznych oraz innych aktorów sceny politycznej nabiera zupełnie nowego wymiaru, co dla badaczy ustroju i regulacji ustrojowych stanowi odkrycie mało dotychczas poznanych obszarów analizy politycznej. Dyskusja na temat przydatności metod indeksowych oraz wyboru adekwatnych indeksów pozwalających mierzyć addytywność, to jest realną siłę polityczną w stosunku do potencjału (wyniku wyborów) była fascynującym przyczynkiem do badań, prowadzonych także przez konstytucjonalistów.

Dwie ostatnie sesje poświęcone były przeglądowi podejść w politologii i zaprojektowane zostały jako podsumowanie całej, niezwykle bogatej i różnorodnej konferencji. W sesjach tych, moderowanych przez prof. dr. hab. B. Szklarskiego i prof. dr. hab. K. Pałeckiego zaprezentowali swoje wyniki badań dr J. Węgrzecki, przedstawiając podejście badawcze Y. Simona w teorii politycznej, dr R. Borkowski, prezentując przydatność perspektywy antropologicznej w badaniu fundamentalizmu i przemocy terrorystycznej, 
mgr Ł. Paw, analizując nurty dyskusji nad sposobami uprawiania politologii empirycznej, a także dr M. Lisiecki, który przedstawił współczesne nurty teorii krytycznej w badaniach nad polityką, dr M. Banaś z prezentacją kategorii Gender w skandynawskiej myśli politycznej oraz dr A. Dybczyński $\mathrm{z}$ analizą sojuszy międzynarodowych jako przedmiotu badań w politologii.

Konferencję doskonale uzupełniała sesja posterowa, prezentująca dokonania młodych badaczy. Szczególną uwagę zwracały analizy, które dotyczyły zastosowań teorii społecznego wyboru i teorii wyboru według Colemana w badaniach zachowań społecznych.

Konferencja „Podejścia badawcze i metodologie w nauce o polityce” zaprezentowała niezmiernie różnorodne, wielokierunkowe i niekiedy mało znane metody i podejścia badawcze stosowane w politologii i innych pokrewnych dziedzinach wiedzy. Szczególnie fascynujące było zestawienie metod wywodzących się z nauk empirycznych, jak metoda abdukcji, czy też metody indeksowe oraz metod czerpiących z dorobku nauk matematycznych i statystyki, jak choćby teoria gier. Wielką zasługą organizatorów konferencji jest zgromadzenie tak wielu badawczy prezentujących niekiedy krańcowo odmienne podejścia do badań politologicznych i ich wzajemna konfrontacja, fascynująca dla uczestników, jak i obserwatorów prezentacji tych metod i podejść badawczych. Wszystkie dyskusje i sesje moderowane były przez najwybitniejszych w kraju badaczy, gwarantujących swym autorytetem naukowym zarówno poziom merytoryczny, jak i formę (metodę) prowadzonej debaty.

Żałować można, że środowisko konstytucjonalistów w zasadzie nie było podczas konferencji reprezentowane, bowiem aplikacja metod prezentowanych podczas konferencji w prawniczych badaniach ustroju mogłaby znacznie wzbogacić i urozmaicić nasze analizy i prace badawcze. Pozostaje żywić nadzieję, że materiały z konferencji doczekają się publikacji książkowej, z którą winni zapoznać się wszyscy uprawiający nauki o polityce, w tym także prawnicy analizujący kwestie ustrojowe.

Anna Młynarska-Sobaczewska (Uniwersytet Łódzki) 